\title{
Extradition in the Framework of International Agreements
}

\author{
Elena Xhina \\ Lawyer, Elbasan \\ PhD Candidate, European University of Tirana \\ xhina_elena@yahoo.com
}

\section{Doi:10.5901/ajis.2014.v3n1p55}

\begin{abstract}
Extradition is a very important institute of criminal law, among other things it is provided by the code penal of the Republic of Albania in order combat to crime, especially in international mutual cooperation to capture and bring before justice offenders of criminal acts. Extradition enables the states to agree and to cooperate to hand over people who have consumed criminal offense from state they are sheltered to state that demands them. In this way it is possible to implement law, combat and prevent crime at the same time. International agreements are based on the basic legal framework that govern the institution of extradition, and precisely in this context will be treated this institute. What is the meaning of this institute? In which forms has it evolved and what perspective does it have? This paper will be focused in these research questions, by treating every issue step by step. The Object of the study for the development of this paper is precisely the concept of extradition, ways of evolution, and the procedure to be followed for its implementation and the expectations in the near future associated with it.
\end{abstract}

Keyword: extradition, international agreement, cooperation, Code of Criminal Procedure, the Penal Code.

\section{Introduction}

The purpose of this study consists in analyzing of the development and prospects of the institute of extradition. Among other things, the development of this topic will be addressed and the report that this institute with international law. Object of study for the development is precisely the concept of extradition, the history, the way of evolution and expectations in the near future associated with.

International cooperation in criminal matters consists in principle of solidarity between different countries of the world. In the difficult process of bringing justice, each state must give his contribution also be assisted by other states. In this way does fulfill successfully the challenges to justice. Through international cooperation the states make possible the realization of a criminal proceeding even where they extend beyond the territory of their jurisdiction. Among the forms that appear in international criminal cooperation such as recognition and enforcement of foreign court decisions, mutual legal assistance, transfer of criminal proceedings and extradition (Hoxha, A. 2010, p. 23), this paper will focus on giving extradition its meaning, history and legal framework.

\section{Understanding the Extradition}

Extradition is a very important institute of criminal law among other things provided by the Penal Code of the Republic of Albania in order to combat crime, especially in international mutual cooperation to apprehend and bring before justice offenders. How did this institute? In which he evolved and what prospect there? It is in these research questions will focus this paper, by addressing any issues with time.

In Article 11 of the Penal Code provided when allowed and is not allowed extradition. As for the meaning of this term refer to Section 488 of the Penal Procedure Code, as well as international legal acts addressing the institute, based on the above, the submission of the author understood the extradition of a criminal from one country to another to execute a sentence of imprisonment or an act proving its for a criminal offense. Conditions that are designed to free movement in the EU countries has created at the same time the possibility that offenders move from one country to another in order to avoid criminal liability and corresponding penitentiary. Extradition agreement enables states to cooperate to deliver sheltered from state to state where that demands such persons who have consumed offense (Muçi, Sh. 2007, p. 89). In this way it is possible to law enforcement, combat and prevents crime at the same time.

To become a person extradited Penal Code requires that two conditions among other essentials: 
First it is necessary to explicitly defined in international agreements to which Albania is a party (Muçi, Sh. 2007, p.90). Rates of the Penal Code and the Penal Procedure Code that govern extradition are in accordance with the Constitution of Albania and affirmed the principles of international legal acts on this issue. It is worth mentioning that it is necessary the existence of bilateral or multilateral agreements, international conventions on extradition so that this institute be applied. Article 39/2 of the Constitution of Albania's extradition relates not only with explicit forecast international agreements but also the obligation to place only by judicial decision. Republic of Albania adheres to international conventions and treaties rather related to extradition. Among them, we can mention the Paris Convention "On Extradition" dated November 13, 1957, the European Convention "On the Transfer of Sentenced Persons", Nr.8499, ratified by Law dated 10.06.1999, the Agreement between Albania and Greece "For Judicial Assistance in criminal, civil and prisoner transfer", dated 17.05.1993, the Council of Europe Convention "On mutual legal assistance in criminal matters", Nr.8498, ratified by Law dated 10.06.1999, the other quite ${ }^{1}$.

The second condition is necessary to forecast the facility requested the extradition request as a criminal offense by Albanian law as well as from foreign simultaneously (Muçi, Sh. 2007, p..91). As the first and this condition is very sensitive site. His absence makes it impossible extradition. It bluntly, if the offense for which extradition is requested is not provided in the provisions of our criminal law then no standing Albanian national authorities to carry out the extradition of the person sought by the foreign state. Conversely, the Albanian state cannot seek the extradition of a person consume offenses of which is not provided as such by the law of the state where he flees. Given the above, there are a group of offenses such as murder, genocide, crimes against humanity, acts of terrorism, prostitution, drug trafficking and other fairly, for which extradition can be accomplished without obstacles as recognized as criminal by all states to accede to the convention which adheres even Albania.

\section{Institute of Historical Overview on Extradition between Albania and other Countries}

If you look at the historical development of the institute extradition to Albania, then will we began the period after independence where our state created a legal basis in connection with this institute and became a party to several important treaties that time. First Treaty of Albania with Greece extradition he recognized the 25 June 1926 (Hoxha, A. 2010, p. 71). After his rank related treaties with Great Britain, Serbia, Croatia and Slovenia. These related treaties in the same year. No less important was the Treaty on Extradition 1933, connected between the United States and Albania, then kingdom (Mici, A. 2004, p.113).

Another period in which we will focus is that after World War II. European countries were divided into two camps. Those who supported and stood allied with the Soviet Union created their international rates. These sites linked quite bilateral agreements with each other regarding the extradition Institute but without forgetting the multilateral agreement by Warsaw as it was. The period of 1944-1990 years for Albania was a period of isolation. This isolation should not be understood only in economic terms but also legal. Albania during that period has become party to international agreements only with the then communist countries. Among them may be mentioned agreements with Russia, Czechoslovakia, Hungary and Romania. However it should be noted that although these agreements exist, extradition relations have been almost nonexistent ${ }^{2}$. This is also due to the fact that the entry or exit of persons from the limit of Albania has been almost impossible. Moving within the country had the sanction of the person shooting. He was eliminated regarded as an enemy of the people with terrorist purposes ${ }^{3}$. Likewise, the emergence of the Albanian border was considered as a criminal offense. This fact therefore explains why extradition in these years was nonexistent.

The period after 1990 was the period when developed cooperative relations between Albania and foreign authorities ${ }^{4}$. After 1990, Albania ratified the agreement fairly and joined several international organizations to improve and bring in another stage of cooperation in criminal matters. Also modernization of legislation, with the entry into force of the Penal Code and the Penal Procedure Code brought its legislation with the European one.

\footnotetext{
${ }^{1}$ QPZ - Summary of International Justice Acts , Tirana 2006

${ }^{2}$ General Summary of Current Law of the People's Socialist Republic of Albania (1945-1985) Volume II , Chapter XIII ( laws regarding foreign relations , p.1525) - Tirana 1986

3 General codification of Current Law of the People's Republic of Albania (1945-1957) Volume III - Publication of the Prime Minister's Office , Tirana 1958

${ }^{4} \mathrm{QPZ}$ - Summary of International Justice Acts, Tirana 2006
} 


\section{The Legal Framework for Extradition Institute}

\subsection{The legal framework on international}

Institute of extradition begins with committing a criminal offense and therefore regulated by criminal procedural law. The latter is a branch where every state has a part of domestic law. But there is a foreign element in this relationship, specifically shelter to fugitive. Necessarily becomes necessary participation of other state bodies to enable cooperation of two countries. This last element, the cooperation between the two countries is characteristic of another branch of law, that of public international law. So about the legal nature of the institute extradition can say that is characterized by elements of different areas of law.

International agreements are basic legal framework governing extradition Institute (Navas, D. 2004, p.39). But this should not be misinterpreted as normative tops, superior over all other acts including international agreements lies Constitution. In the Republic of Albania ratified international agreements occupy second place in the hierarchy of legal norms 5 . So in case of conflict with the Constitution a treaty can be hit, but in relation to other laws he rules. However in connection with extradition agreements Institute have a primary role and the forms in which they appear are precisely three (Hoxha, A. 2010, p.50). The first forms are treaties that followed the submission of evidence by the execution of extradition offenses listed accomplished by leading to the extradition of a person. This method is also called the listing. The second form is characterized by the method of eliminating the submission of facts, and has a special ability that no one party to change the content of the agreement through a domestic law. The consent of the other party, so it is not necessary as long as it has not declared any reservations about the method of elimination, is then automatically freed the way for a possible change. Regarding the third form of performance agreements in connection with the extradition can say that is a fusion of two forms of the above, then a mixture of the characteristics of two forms of money that would be the combination of the method of listing with him elimination.

According to the Vienna Convention "On the Law of Treaties" and specifically its article 30, third paragraph, in cases where a later treaty are parties all the earlier treaty but the latter is not suspended or ceased acting, then it applies only to the extent that its provisions are in accordance with the provisions of the treaty. Based on the meaning of this paragraph, may affirm that international law presumes that as a rule through the second agreement supersede the original agreement the parties tacitly. But this general rule there will be exceptions where both compete agreements will be applied at the same time. These are cases where some part of the existing extradition treaty match later. Another case when the clauses have the agreement made subsequent extradition treaty references to earlier. Finally, the exception to the general rule when we have an extradition agreement later introduced as complementary to the existing treaty. Here the first agreement remains foremost after the second agreement also complementary, is destined to pursue her legal fate.

\subsection{The main conventions to which the Republic of Albania is a party}

- $\quad$ European Convention "On Extradition " and its two Additional Protocols, 1998.

- $\quad$ UN Convention "On cross-border organized crime " and its two Additional Protocols, 2002.

- UN Convention against illicit traffic in narcotic drugs and raw Psychotropic Substances, 2000.

- European Convention "On protection of human rights and fundamental freedoms", in 1996.

- European Convention "On the transfer of sentenced persons", in 1999.

- European Convention "On mutual legal assistance in criminal matters" and it's Additional Protocols, $1999^{6}$.

- $\quad$ European agreement "For the transmission of requests for judicial assistance".

- European Convention "On the validity of international criminal trials", in 2003.

- European Convention "On the transfer of criminal proceedings", in 1999.

- European Convention "On supervision of persons convicted or paroled", in 2000.

- European Convention "On Laundering, Search, Seizure and Confiscation of products crime", in 2000.

- European Convention "On Suppression of Terrorism" in 20007.

${ }^{5}$ QPZ - The Constitution of the Republic of Albania, Tirana 2010

${ }^{6}$ QPZ - Summary of International Justice Acts , Tirana 2006 


\subsection{Bilateral international agreements to which the Republic of Albania adheres}

- Extradition agreement with the United States, in 1935.

- Extradition treaty with Great Britain, in 1927.

- Bilateral Agreement with the Arab Republic of Egypt "Extradition", in 2004.

- Bilateral agreement with Greece "On the transfer of persons Convicted", in 1993.

- Bilateral agreement with Turkey, "On mutual legal assistance in civil, criminal and Commercial", in 1995.

- Bilateral Agreement with Macedonia "On mutual legal assistance in criminal and civil", in $1998^{8}$.

- Bilateral agreement with Russia "On mutual legal assistance in civil, criminal and family", in 1996.

- Bilateral agreement with Italy "On the transfer of sentenced persons" in 2004.

- Bilateral agreement with Italy "For an extra in the European Convention Extradition", in 2008.

- Bilateral agreement with Hungary to fight against crime, in 2000.

- $\quad$ Agreement with Slovenia for the fight against crime, in 1998.

- Convention on legal assistance to the Democratic Republic of Germany ${ }^{9}$.

\subsection{The legal framework under the domestic law of the Republic of Albania}

Republic of Albania Constitution as the fundamental law of the state provides the main principles regarding extradition. If we refer to Article 39, will note that our Constitution provides that extradition is allowed only if there is international agreement on this and Albania is a party. Also note that this can be done only by a court decision. Another principle that we can mention is the failure to adjudicate twice for the same offense, specifically expressed in Article 34 of the Constitution. This is very important in connection with the Institute of extradition cannot be done after the extradition of a person, to whom a decision is given by the state where he is for the offense for which required. Albanian state constitution also pays principles concerning due process, the absorption of international norms and adapt their internal state rates.

Criminal Procedure Code of the Republic of Albania attaches great importance jurisdictional relations with foreign authorities. More specifically in Title X, Chapter I, Sections I and II, provided that the relevant provisions governing the procedure to be applied for the extradition of a person to overseas and from overseas. Article 488 to Article 504 of the code dedicated this institute, ranging from understanding the extradition of continuing with the whole procedure to be followed by the relevant authorities. The following sections define the form in which the request for extradition presented, moreover, cases of refusal of this application, the conditions for extradition, prosecution action it takes, austerity measures, seizures, arrest procedure by judicial police. Further defined in Section 498, where the court gives a decision in favor or against extradition, continuing with the following articles regarding the suspension of delivery, transit, costs ... etc., and ending with section 504, which provides that the competent authority is the Ministry of Justice with its dues in connection with the request for extradition from overseas. In order to expand more in the next section will examine the extradition proceedings under the relevant provisions of the Penal Procedure Code being reviewed and analyzed more thoroughly the respective sections of this code regarding this institute of law.

Last but not least as part of domestic legislation governing extradition relations cannot rank the Criminal Code of the Republic of Albania. In the first setting forth general provisions of this code, specifically in Article 11, shall be determined where and when allowed cannot be allowed extradition of a person. In this article clearly stated primary conditions without the presence of which cannot be enforced concrete procedures to extradite an individual. Not for nothing that regulates this article institute lies with the general provisions stipulating and other principles of criminal law and specifically in the first chapter, which deals with criminal law and its implementation. Just as important are plenty of other principles such as criminal law enforcement for offenses committed by foreign nationals or the power of criminal decisions of foreign courts ... etc., but so has the importance of extradition institute through which power law becomes more efficient without creating the possibility that people who consume offenses to avoid this responsibility.

\footnotetext{
7 Stoja. E (Prokuroria për Krimet e Rënda) - Ekstradimi, ndikimi i konventave ndërkombëtare dhe marrëveshjeve dypalëshe. Jurisprudenca e Gjykatës së Lartë - Shkolla e Magjistraturës (Programi i Trajnimit Vazhdues), Tiranë 16-17 mars 2010

${ }^{8}$ QPZ - Summary of International Justice Acts , Tirana 2006

${ }^{9}$ Stoja. E (Prokuroria për Krimet e Rënda) - Ekstradimi, ndikimi i konventave ndërkombëtare dhe marrëveshjeve dypalëshe. Jurisprudenca e Gjykatës së Lartë - Shkolla e Magjistraturës (Programi i Trajnimit Vazhdues), Tiranë 16-17 mars 2010 


\section{References}

Elezi, I. (2009), Criminal Law (general part), Erik publications, Tirana

Elezi, I., Kaçupi, S., Haxhia, M. (1999), Commentary of the Criminal Code of the Republic of Albania, Tirana

Hoxha, A. (2010), Extradition under the legal instruments of the European Union. Similarities and differences with the Council of Europe instruments, Morava, Tirana

Islami, H., Hoxha, A., Panda, I. (2007), Criminal Procedure, Morava Publications, Tirana

The Constitution of the Republic of Albania, Publication of Official Publications Center Tirana

Criminal Code of the Republic of Albania, April 2009, Publication of Official Publications Center Tirana

Criminal Procedure Code of the Republic of Albania, April 2009, Publication of Official Publications Center Tirana

General codification of Current Law of the People's Republic of Albania 1945-1957, Volume III, (1958), Publication of the Prime Minister's Office, Tirana

European Convention on Extradition, unofficial translation

Vienna Convention on the Law of Treaties

The European Convention on Legal Assistance in Criminal

Law No. 8322, dated 02.04.1998 "On the Ratification of the Council of Europe Convention on Extradition and the two Additional Protocols"

Law No. 8498, dated 10.06.1999 "On the Ratification of the Convention of the Council of Europe 'For Mutual Legal Assistance in Criminal Matters' and its additional protocol"

Law No. 8883, dated 18.04.2002 "On the Ratification of the Additional Protocol II Council of Europe Convention on Mutual Assistance in Criminal Matters"

Law No. 10426, dated 02.06.2011 "On the Ratification of the Third Additional Protocol to the European Convention on Extradition"

Mici, A. (2004), Jurisdictional relations with foreign authorities, School of Magistrates

Muci, Sh. ( 2007), Criminal Law (general part), Editions Dudaj, Tirana

Myrtja, Y. ( 2005), Legal Magazine No.2 (Legal Studies), University of Tirana

Myrtja, Y. (2012), Lectures on Criminal Law (Institute of Extradition), European University of Tirana (UET), Tirana

Navas, D. (2004), European Extradition System, Lectures held at the School of Magistrates

Nicholls, C., Montgomery, C., Knowles, J., (2007), The law of extradition and mutual assistance, Oxford Univ Press

Nowicki, A. (2003), About the European Convention on Extradition

General Summary of Current Law of the People's Socialist Republic of Albania (1945-1985) Volume II, Chapter XIII, Laws regarding foreign relations, page 1525 (1986), Tirana

Summary of International Justice Acts, (2006), Publication of Official Publications Center Tirana

Spiro, S. (2010), Lectures on Criminal Law (Institute of Extradition), European University of Tirana (UET), Tirana

Stoja, E. (2010), The Serious Crimes Prosecution, Extradition, the impact of international conventions and bilateral agreements. The jurisprudence of the Supreme Court, School of Magistrates (Continuous Training Program), Tirana 
